\title{
Każda reprezentacja jest interpretacją - w stronę hermeneutycznej koncepcji architektury informacji
}

\author{
Marcin Roszkowski \\ ORCID 0000-0001-7396-4685 \\ Katedra Informatologii, Wydziat Dziennikarstwa, Informacji i Bibliologii, \\ Uniwersytet Warszawski
}

\begin{abstract}
Abstrakt
Cel/Teza: Celem artykułu jest próba charakterystyki architektury informacji (AI) z punktu widzenia możliwości zastosowania hermeneutyki jako teorii, która może wyznaczać pewne ramy interpretacyjne dla tego obszaru badawczego oraz dać jego podstawy epistemologiczne i metodologiczne. Punktem wyjścia do rozważań jest teza L. Rosenfelda, P. Morville’a i J. Arango o roli rozumienia $\mathrm{i}$ interpretacji w projektowaniu architektury informacji.

Koncepcja/Metody: W warstwie metodologicznej artykuł opiera się na interpretacji modelu architektury informacji autorstwa L. Rosenfelda, P. Morville’a i J. Arango z punktu widzenia założeń hermeneutyki H. G. Gadamera oraz cyfrowej hermeneutyki R. Capurro.

Wyniki i wnioski: Zastosowanie podejścia hermeneutycznego zarówno do projektowania jak i badania architektury informacji wyznacza określoną postawę poznawczą, w której przyjmuje się założenie o kulturowych i kontekstualnych determinantach organizacji wiedzy oraz wprowadza się koncepcję przed-sądów, które tworzą horyzont rozumienia użytkowników informacji. W takim ujęciu AI wiąże się z projektowaniem pewnej oferty znaczeniowej, której środkiem ekspresji są systemy organizacyjne, etykietowania, nawigacji i wyszukiwania. Proces rozumienia tej oferty polega na hermeneutycznej koncepcji fuzji otwartego horyzontu rozumienia użytkownika i zamkniętego i zaprojektowanego horyzontu systemu informacyjnego. Proces rozumienia zachodzi w trakcie specyficznego rodzaju konwersacji użytkownika z systemem, którego ramy wyznacza model interakcji.

Oryginalność/Wartość poznawcza: Postawy poznawcze charakterystyczne dla hermeneutyki i fenomenologii hermeneutycznej widoczne są w dyskursie w ramach architektury informacji. Mają one charakter raczej heurystyk, nie zaś spójnej refleksji teoretycznej. Zaproponowany zarys hermeneutycznej koncepcji architektury informacji może stanowić punkt wyjścia do dyskusji nad teorią AI, szczególnie w kontekście prób uczynienia z niej dyscypliny akademickiej.
\end{abstract}

\section{Słowa kluczowe}

Architektura informacji. Cyfrowa hermeneutyka. Hermeneutyka. Interakcja człowiek-komputer. Organizacja informacji.

Otrzymany: 28 października 2019. Zrecenzowany: 19 listopada 2019. Poprawiony: 21 listopada

2019. Zaakceptowany: 25 listopada 2019.

\section{Wprowadzenie}

W 2018 r. minęło 20 lat od opublikowania pierwszego wydania książki Architektura informacji w serwisach internetowych autorstwa Louisa Rosenfelda i Petera Morville'a (1998). 
Publikacja ta uznawana jest za pierwsze syntetyczne przedstawienie koncepcji organizacji informacji w serwisach internetowych, które przyczyniło się do rozpowszechnienia terminu architektura informacji oraz wzrostu zainteresowania tą problematyką. Chociaż sam termin (architekt informacji) został użyty po raz pierwszy przez Saula Wurmana w latach 70. XX w. (Resmini \& Rosati, 2011), to za twórców tzw. nowoczesnej architektury informacji uznaje się właśnie Rosenfelda i Morville’a. Koncepcja architektury informacji (AI) przedstawiona $\mathrm{w}$ ich książce zakłada przede wszystkim strukturalną perspektywę poznawczą ${ }^{1} \mathrm{w}$ badaniu i projektowaniu sieciowych usług informacyjnych w postaci serwisów internetowych i systemów intranetowych. Wraz z rozwojem i upowszechnieniem się nowych technologii informacyjno-komunikacyjnych (np. urządzenia mobilne, rzeczywistość rozszerzona), w kolejnych wydaniach tej książki autorzy sukcesywnie rozszerzali obszar zainteresowań AI (Morville \& Rosenfeld, 2002, 2008; Morville et al., 2015).

Od początku AI była związana z działalnością praktyczną, czyli projektowaniem strukturalnym współdzielonych środowisk informacyjnych (Morville et al., 2015, 21). Równocześnie, obok działalności praktycznej w środowisku osób zajmujących się AI, pojawiły się próby naukowego spojrzenia na problemy, które AI próbuje rozwiązać oraz pewne refleksje natury metodologicznej. W samej publikacji Rosenfelda i Morville'a obecne są treści wpisujące się w to ujęcie, jednak wysoki poziom ich ogólności skłania do wniosku, że książka ta w założeniu miała być raczej wprowadzeniem do problematyki projektowania AI, nie zaś podręcznikiem czy kompendium wiedzy na temat AI. Podczas prób naukowej refleksji nad AI wyłonił się też problem definicyjny. Budowa spójnej koncepcji AI wiązała się z koniecznością wprowadzenia terminu oraz zaproponowania definicji, która będzie akceptowana przez społeczność praktyków i teoretyków. Christina Wodtke (2001) zgromadziła kilkanaście definicji terminu lub prób wyjaśnienia jego znaczenia, które były w obiegu do 2001 r. pokazując jednocześnie brak zgody, co do jego ram interpretacyjnych. W 2005 r. Andrew Dillon, ówczesny dziekan School of Information w University of Texas oraz jeden z pierwszych badaczy AI wywodzący się z bibliologii i informatologii, stwierdził że nie posiadamy ogólnie akceptowanej definicji terminu architektura informacji i takiej nie potrzebujemy (Resmini \& Rosati, 2011,30). W ten sposób odniósł się do definiowania AI w kategoriach sztuki użytkowej i zauważył, że w takim ujęciu AI nie jest w stanie zagwarantować powtarzalności w odniesieniu do procesów projektowania. Mamy więc do czynienia z elementem intuicji w projektowaniu AI, co w kontekście nadania jej badawczego charakteru oraz wprowadzenia jako programu nauczania na poziomie akademickim, może powodować poważne problemy.

Analizując rozwój AI, można dostrzec pewne symptomy uczynienia z niej dyscypliny naukowej lub kierunku badawczego. Obok społeczności praktyków ukonstytuowały się społeczności badaczy, którzy identyfikują problemy badawcze oraz proponują rozwiązania o charakterze metodologicznym. Praktycy i teoretycy zawiązują organizacje i stowarzyszenia (np. Information Architecture Institute ${ }^{2}$ ), organizują warsztaty i konferencje zarówno o zasięgu lokalnym, jak i międzynarodowym (np. IA Summit), tworzą dedykowane kanały

\footnotetext{
${ }^{1}$ Rozstrzygnięcie problem statusu architektury informacji nie jest głównym celem tego artykułu. Należy jednak zasygnalizować, że zagadnienie to było i nadal jest przedmiotem dyskusji (np. Brown, 2010; Haverty, 2002; Lacerda \& Lima-Marques, 2014; Andrea Resmini, 2014).

2 Information Architecture Institute działał od 2002 r. do września 2019 r.
} 
dystrybucji informacji w postaci czasopism branżowych (np. Journal of Information Architecture) oraz inicjują próby usystematyzowania terminologii, np. The Glossary of Information Architecture (Hagedorn, 2000). Wydaje się więc, że infrastruktura badawcza skupiona wokół AI po 20 latach od pojawienia się tej koncepcji doprowadziła do uporządkowania teoretycznej refleksji na temat tego obszaru i udzielenia odpowiedzi na pytanie o jego tożsamość lub wskazania na związki z innymi dyscyplinami naukowymi (Skórka, 2016a). Spójna teoria, metodologia oraz epistemologia AI jest potrzebna zarówno dla prowadzenia badań, jak i dydaktyki. Zapewniają one bowiem możliwość realizacji podstawowych funkcji dyscyplin naukowych, jakimi są wyjaśnianie i przewidywanie zjawisk będących przedmiotem ich zainteresowania. Problem ten był również sygnalizowany w polskiej literaturze przedmiotu z obszaru bibliologii i informatologii (Skórka, 2002, 2016b, 2016a; Tafiłowski, 2016).

\section{Cel i przedmiot badań}

Celem artykułu jest próba przyjrzenia się architekturze informacji z punktu widzenia możliwości zastosowania hermeneutyki jako teorii, która może wyznaczać pewne ramy interpretacyjne dla tego obszaru badawczego i dać jego podstawy epistemologiczne i metodologiczne. Przedmiotem rozważań jest koncepcja AI zaproponowana przez Rosenfelda i Morville'a, która proponuje określoną metodykę projektowania narzędzi organizacji informacji w serwisach internetowych. W warstwie metodologicznej artykuł opiera się na analizie i krytyce literatury przedmiotu oraz interpretacji modelu architektury informacji autorstwa Rosenfelda, Morville’a i Jorge Arango (2015), z punktu widzenia założeń hermeneutyki Hansa-Georga Gadamera (2013) oraz cyfrowej hermeneutyki Rafaela Capurro (2000, 2010).

\section{Problem (braku) teorii w architekturze informacji}

W dyskursie naukowym dotyczącym AI od początku możemy zidentyfikować dwie postawy poznawcze, które determinują ramy interpretacyjne dla tego pojęcia. Pierwsza z nich zakłada szeroką interpretację projektowania i organizowania przestrzeni informacyjnych i można ją utożsamiać z ujęciem ekologii informacji, która bada „wzajemne relacje między ludźmi (ich kondycją, potrzebami i zachowaniami informacyjnymi) a technologiami informacyjnymi i środowiskiem informacyjnym" (Materska, 2017, 611). Taka interpretacja AI w centrum stawia człowieka, jego interakcje ze środowiskiem informacyjnym na wielu płaszczyznach i nie jest zdeterminowana technologicznie. Andrew Dillon (2002) określa to ujęcie mianem dużej architektury informacji (ang. big IA), której przeciwstawia koncepcję małej architektury informacji (ang. little IA). Ta podejmuje problemy organizacji informacji w środowisku World Wide Web. To wąskie pojmowanie AI jest zbieżne z koncepcją Rosenfelda i Morville'a i w centrum stawia system informacyjny, który funkcjonuje w określonym otoczeniu i ma realizować określone funkcje.

Te dwie interpretacje AI determinują charakter teoretycznych dociekań na temat jej natury. W przypadku szerokiej interpretacji AI warto wspomnieć o koncepcji „wszechobecnej 
architektury informacji” (ang. pervasive information architecture), którą zaproponowali Andrea Resmini i Luca Rosatti (2011). Przedstawiają oni holistyczne ujęcie AI, które wpisuje się w ujęcie ekologii informacji, wychodząc poza sieciowe środowisko informacyjne i traktując przestrzenie informacyjne, w których funkcjonuje człowiek jako ekosystem, unikając jednocześnie technologicznego determinizmu. Resmini (2013) definiuje AI jako multidyscyplinarny konstrukt kulturowy, którego przedmiotem jest integralność znaczeniowa w złożonych, wielokanałowych ekosystemach informacyjnych ${ }^{3}$. Koncepcja ta została rozwinięta w postaci zbioru artykułów opublikowanych w pracy zbiorowej pod redakcją A. Resmini Reframing Information Architecture (Resmini, 2014). Publikacja ta jest o tyle istotna, że przedstawione teoretyczne rozważania na temat AI ewidentnie wskazują jednak na jej transdycyplinarny charakter (Lacerda \& Lima-Marques, 2014, 4). Ekologiczna interpretacja AI obecna jest również w publikacjach Morville’a (2005, 2014) i Arango (2018).

Rozważania teoretyczne na temat architektury informacji w wąskim ujęciu koncentrują się przede wszystkim na aspektach metodycznych w projektowaniu cyfrowych przestrzeni informacyjnych. Na wczesnym etapie jej rozwoju, tj. w 2002 r. Marsha Haverty (2002), poddając krytyce jej założenia teoretyczne stwierdziła, że AI może być postrzegana jako pole badawcze, ale nie osiągnęła jeszcze statusu dyscypliny naukowej m.in. z powodu braku wewnętrznych teorii naukowych. W konsekwencji Haverty traktuje IA jako indukcyjny proces projektowania przestrzeni informacyjnych (w odniesieniu do małej architektury informacji), w dostępie do których wykorzystuje się interaktywne technologie informacyjne. Indukcyjny charakter tego procesu jest konsekwencją braku podstaw teoretycznych, co powoduje, że każdy projekt traktowany jest jako unikalny fenomen, który w procesie projektowania wyłania się na skutek dołączania do niego kolejnych elementów strukturalnych (ang. emergent phenomena). W ramach projektu AI identyfikuje się problemy projektowe (ang. design problems), które projektanci rozwiązują od początku, z zerowymi założeniami, bez odniesienia do jakiejkolwiek teorii, która dałaby ich spójną wykładnię. W związku z brakiem refleksji teoretycznej dotyczącej problemów, z jakimi mierzy się AI, Haverty proponuje zastosowanie metodologii konstruktywnej indukcji (ang. constructive induction) przejętej z dziedziny uczenia maszynowego (ang. machine learning) oraz inżynierii wiedzy (Haverty, 2002, 840).

Dan Brown (2010) opracował ramy metodyczne dla AI w postaci ośmiu ogólnych zasad projektowych, które kierują tym procesem, gdzie przyjmuje się trzy założenia początkowe: (1) rozdzielenie warstwy organizacji informacji od warstwy jej prezentacji; (2) konieczność posiadania wiedzy na temat potrzeb i zachowań użytkowników docelowych; (3) konieczność posiadania wiedzy na temat formy i treści zasobów informacyjnych będących przedmiotem organizacji. Jego perspektywa badawcza również jest osadzona w bibliologii i informatologii.

Zaproponowany przez Rosenfelda i Morville’a model AI zakłada funkcjonowanie trzech wzajemnie powiązanych ze sobą elementów: użytkownik - zawartość - kontekst (ang. user - content - context). Taka perspektywa determinuje proces projektowania AI, a z badawczego punktu widzenia może wyznaczać określone podejścia teoretyczne w dociekaniach metodologicznych i epistemologicznych. Dwa najbardziej „stabilne” z poznawczego punktu widzenia elementy tego modelu odnoszą się do zasobu informacyjnego będącego

\footnotetext{
${ }^{3}$ Oryg: multi-disciplinary sense-making cultural construct concerned with the structural integrity of meaning in complex, information-based cross-channel ecosystems (Resmini, 2013, 31).
} 
przedmiotem organizowania (zawartość) oraz potrzeb i zachowań informacyjnych docelowych użytkowników danego systemu informacyjnego czy usługi informacyjnej (użytkownik). W przypadku AI oznacza to możliwość czerpania z teorii i metodologii innych dyscyplin naukowych, np. bibliologii i informatologii (reprezentacja informacji, organizacja wiedzy, badania nad użytkownikami informacji) czy interakcji człowiek-komputer.

O ile zasadniczym celem AI jest projektowanie strukturalne współdzielonych środowisk informacyjnych (Morville et al., 2015, 21), o tyle założenia takich projektów oraz przyjęte rozwiązania są często zdeterminowane pojedynczą sytuacją projektową, na którą wpływ mają przede wszystkim elementy składające się na trzecią część modelu - kontekst. To określone cele (w tym biznesowe), strategie (w tym marketingowe) oraz przyjęta polityka informacyjna zleceniodawcy wprowadzają określone ograniczenia w założeniach projektowych i determinują przyjęte rozwiązania w zakresie organizacji informacji. Morville, Rosenfeld i Arango zauważają, że kluczem do uwzględnienia elementu kontekstu w projektowaniu AI jest pojęcie zrozumienia i dostosowania się (Morville et al., 2015, 33). Polega to z jednej strony na jawnym określeniu celów usługi informacyjnej i strategii, w którą wpisuje się jej funkcjonowanie na podstawie informacji od zleceniodawcy oraz uwzględnieniu aspektu kulturowego zarówno w szerokim znaczeniu jak i w odniesieniu do kultury organizacyjnej podmiotu zlecającego. Z drugiej strony element kontekstowy powinien uwzględniać również rodzaj technologii pośredniczącej między użytkownikiem a usługą informacyjną, która w znaczący sposób może wpłynąć na zastosowane techniki i narzędzia organizacji informacji.

Interpretacja kontekstu jako trzeciego elementu modelu AI zaproponowana przez Morville, Rosenfeld i Arango kładzie nacisk na cele realizowane przez usługę informacyjną, które tak jak cała koncepcja AI w ich wydaniu są ściśle związane z aspektem komercyjnym sieciowych usług informacyjnych. Z badawczego punktu widzenia wiąże się to z zastosowaniem metod i technik badania kultury organizacyjnej danego podmiotu z punktu widzenia wymogów funkcjonalnych systemu informacyjnego realizującego jego wybrane strategie i cele.

Kontekst jako element AI może jednak być postrzegany z punktu widzenia użytkownika. Takie ujęcie proponuje Andrew Hinton w swojej ekologicznej koncepcji AI, gdzie kontekst definiowany jest jako sposób, w jaki dana osoba postrzega relacje między elementami tworzącymi środowisko jej funkcjonowania. Kontekst jest więc relacją, która zachodzi między osobą i jej otoczeniem w postaci pewnej konceptualizacji (rozumienie), nie zaś cechą, która istnieje poza nią (Hinton, 2014, 25-26). Zarówno w ujęciu Morville’a, Rosenfelda i Arango, jak i u Hintona mamy więc do czynienia z pojęciem rozumienia otoczenia, ale ujmowanym z dwóch różnych perspektyw. Rozumienie zakłada konieczność interpretacji i wyjaśniania, a skoro występuje ono jako kluczowy element definicyjny kontekstu w modelu AI, to można postawić pytanie o rolę rozumienia i interpretacji zarówno w projektowaniu, jak i badaniu AI, i poszukiwać pewnych ram teoretycznych dla wyjaśnienia tego problemu.

\section{Główne założenia hermeneutyki}

Rozumienie i interpretacja to dwa pojęcia będące przedmiotem badań hermeneutyki, przez którą rozumie się metodologię interpretacji sensownych działań ludzkich i ich efektów, najczęściej w postaci tekstów (Mantzavinos, 2016). Korzenie hermeneutyki sięgają 
starożytnej Grecji i sztuki interpretacji tekstów literackich. Metodologia ta miała również zastosowanie w teologii w analizie tekstów świętych. Hermeneutyka filozoficzna zapoczątkowana w XIX w. przez Friedricha Schleiermachera rozszerzyła przedmiot swoich badań również na inne teksty jako wytwory działalności intelektualnej i artystycznej człowieka.

Wewnątrz hermeneutyki możemy wyróżnić dwa stanowiska epistemologiczne. W pierwszym znaczenie tekstu jest osadzone bezpośrednio w jego treści, w drugim znaczenie realizuje się w procesie jego rozumienia, w którym tekst, proces jego tworzenia i interpretacja jego treści odgrywają kluczową rolę. W ujęciu obiektywistycznym, tekst posiada znaczenie niezależne od aktu jego interpretacji. Celem hermeneutyki jest dostarczenie metody jego obiektywnej analizy, która wyeliminuje wcześniejsze założenia interpretatora i dokona całkowitej dekontekstualizacji tekstu. Po przeciwnej stronie sytuuje się podejście, w którym kluczową rolę pełni interpretacja rozumiana jako interakcja między pewnym horyzontem rozumienia, który wnosi tekst a horyzontem rozumienia, którym dysponuje jego czytelnik. Twórcą tej koncepcji jest Hans Georg Gadamer i zakłada ona, że każdy akt odczytania czy odsłuchania tekstu wiąże się z nadaniem mu znaczenia poprzez proces jego interpretacji (Winograd \& Flores, 1987, 28).

Jak pisze Rafał Ilnicki, według filozofii Gadamera „do żadnych obiektów i procesów nie podchodzimy jako istoty puste interpretacyjnie, to znaczy, że posiadając określone przed-rozumienie rzutujemy je na sposób odczytania świata oraz w nim działania" (Ilnicki, 2012, 49).

Owo przed-rozumienie nazywane również przed-sądem (ang. pre-judgement) odnosi się do tezy Gadamera, że „nasze rozumienie warunkowane jest przez wiele nieświadomych, wstępnych przesądzeń i przeświadczeń” (Przyłębski, 2006, 27). Nasze przed-sądy są otwarte na zmiany wraz z tym jak doświadczamy świat i sytuacje, które nas w nim spotykają. Zarówno nasze przed-sądy jak i przeszłe doświadczenia tworzą nasz horyzont zrozumienia, który tak jak nasze przed-sądy nie jest statyczny ani niezmienny, lecz w procesie poznania jest podatny na zmiany (Malpas, 2016). Pojęcie horyzontu zrozumienia Magdalena Maszkiewicz wyjaśnia następująco:

Warunkiem możliwości rozumienia jest istnienie horyzontu myślowego współdzielonego przez odbiorcę i tekst, a czytelnik nie może się wyizolować od przekonań, które już wcześniej włączył do swojego sposobu myślenia (chociaż może je zmienić pod wpływem tekstu) (Maszkiewicz, 2015, 3-4).

Proces rozumienia polega na stapianiu się (lub fuzji) horyzontów a język jest podmiotem i przedmiotem doświadczenia hermeneutycznego (Oziębłowski, 2006, 68). Zdaniem Matthew Chalmersa, pojęcie interpretacji w filozofii Gadamera powinno być rozumiane jako interakcja zachodząca między aktywnością czytelnika, jego przed-sądami i kontekstem, w którym się znajduje (jego horyzontem myślenia) a treścią i uwarunkowaniami kontekstowymi informacji zawartymi w tekście (jego horyzontem). Interpretacja jest oparta na przed-sądach, na które składają się założenia obecne w języku, którym posługuje się dana osoba. Uczymy się używać języka poprzez nowe doświadczenia i interpretacje (Chalmers, 2004, 214). Proces rozumienia przyjmuje formę koła hermeneutycznego, którego koncepcję Gadamer przejął i rozwinął od Martina Heideggera. Ma ono formę ruchu kolistego i zakłada konieczność interpretacji części w odniesieniu do całości, którą współtworzy oraz całości w odniesieniu do jej elementów konstytutywnych. Ruch w procesie rozumienia rozpoczyna się od całości, poprzez jej części i z powrotem do całości. Podmiot poznający w akcie interpretacji nigdy nie jest w pozycji neutralnej, przeciwnie - przystępuje do procesu poznania z całym bagażem swoich przed-sądów tworzących jego horyzont 
rozumienia. Koło hermeneutyczne zakłada więc różne fazy analityczne: od dekonstrukcji (rozumienie), przez analizę (wyjaśnianie) do interpretacji (nowe rozumienie), itd. (Cole \& Avison, 2007, 825).

Filozofia hermeneutyczna jest wykorzystywana w nauce zarówno jako postawa epistemologiczna, jak i metodologiczna. W pierwszym ujęciu mamy do czynienia z zastosowaniem np. fenomenologii hermeneutycznej Martina Heideggera jako próby wyjaśnienia procesu poznania. W drugim, hermeneutyka wpisuje się w podejście interpretatywne w metodologii nauk. Perspektywa hermeneutyczna jest również obecna w dyscyplinach naukowych związanych z architekturą informacji, tj. bibliologią i informatologią oraz interakcją człowiek-komputer. W dyskursie naukowym obecne jest zagadnienie zastosowania metodologii hermeneutycznej w projektowaniu systemów informacyjnych (Chalmers, 2004; Cole \& Avison, 2007; Myers, 1994), systemów organizacji wiedzy (Mai, 1998; Mazzocchi \& Bosch, 2008), czy też w procesie interakcji z cyfrowymi usługami informacyjnymi (Jahnke, 2011; Voida, 2008; Winograd \& Flores, 1987).

\section{Cyfrowa hermeneutyka}

Z uwagi na fakt, że przedmiotem architektury informacji w wąskim znaczeniu są cyfrowe usługi informacyjne realizowane w większości z wykorzystaniem środowiska World Wide Web, warto w tym miejscu przedstawić kontekst dalszych rozważań i zastanowić się, jak przenieść założenia hermeneutyki na grunt środowiska elektronicznego. W tym celu można przywołać koncepcję cyfrowej hermeneutyki Rafaela Capurro. Wyznacza ona pewne ramy interpretacyjne dla hermeneutyki zarówno w ujęciu epistemologicznym, jak i metodologicznym. Według Capurro cyfrowa hermeneutyka jest rozumiana jako spotkanie hermeneutyki z technologią informacyjną w szczególności z Internetem (Capurro, 2010, 35). Celem cyfrowej hermeneutyki jest badanie związków między procesem interpretacji informacji przez człowieka a aplikacjami sieciowymi, za pośrednictwem których ten proces zachodzi (van den Akker et al., 2011, 1). Capurro przyjmuje tutaj szeroką interpretację uczestnictwa człowieka i społeczności w przestrzeni cyfrowej i nawiązuje do fenomenologii Heideggera i jego koncepcji bycia-w-świecie (Heidegger, 2008). Capurro (2010, 37) stawia tezę, że

jeżeli przyjmiemy, że sposób w jaki postrzegamy rzeczywistość i formułujemy nasze sądy jest ukształtowany hermeneutycznie przez technologie cyfrowe, z których korzystamy i odwrotnie, to na podstawie tego założenia możemy wywnioskować, że technologie cyfrowe muszą dostosować się do tego, w jaki sposób postrzegamy i interpretujemy rzeczywistość. W innym wypadku będą one bezużyteczne, a w najgorszym razie niebezpieczne ${ }^{4}$.

Capurro odnosi się również do figury koła hermeneutycznego w kontekście sieciowego paradygmatu środowiska cyfrowego. Twierdzi, że w obecnych czasach cyfryzacja dokonała hybrydyzacji koła hermeneutycznego. Społeczeństwa XXI w. poszukują właściwego sposobu wejścia do sieci cyfrowej. Oznacza to, że koło hermeneutyczne jako metafora

${ }^{4}$ Oryg.: If we argue that the ways we perceive reality and the thoughts we develop are shaped hermeneutically by our digital technologies and vice versa, then it can be inferred that digital technologies have to adapt to the ways we perceive and interpret reality, otherwise they will be irrelevant to our purpose and, in the worst case, dangerous. 
hermeneutyki filozoficznej powinno zostać zreinterpretowane jako sieć hermeneutyczna (Capurro, 2010, 39). Koncepcja cyfrowej hermeneutyki Capurro z pewnością wymaga szerszego komentarza, jednak ten wykracza poza zakres artykułu. W tym miejscu należy jednak podkreślić, że technologie informacyjno-komunikacyjne na wielu płaszczyznach determinują sposób naszego poznania, interpretacji i rozumienia treści i zjawisk.

Przyjmując perspektywę informatologiczną, w której interesują nas procesy informacyjne, również możemy odnaleźć miejsce dla ujęcia hermeneutycznego. Capurro twierdzi, że możliwa jest hermeneutyczna interpretacja procesów przechowywania i wyszukiwania informacji jako artykulacji relacji między egzystencjalną otwartością świata użytkownika systemu, jego wieloma otwartymi na zmiany horyzontami przed-rozumienia a określonym i zamkniętym horyzontem systemu informacyjnego. Jego zdaniem poszukiwanie informacji jest procesem interpretacji, w którym mamy do czynienia z kontekstem (życiowym) osoby poszukującej oraz ludźmi, którzy przechowują różne rodzaje wypowiedzi językowych, którym nadano określone znaczenie w przyjętym w danym systemie kontekście zrozumienia (np. z wykorzystaniem tezaurusów, słów kluczowych, klasyfikacji) (Capurro, 2000). Warto tu podkreślić różnicę między otwartym charakterem horyzontu rozumienia użytkownika oraz zamkniętym i zaprojektowanym horyzontem systemu ${ }^{5}$. Zdaniem Capurro (2000) w odniesieniu do projektowania systemów informacyjnych oznacza to określone konsekwencje:

(1) W projektowaniu systemu organizacji wiedzy dla danego systemu mamy do czynienia z konceptualną fragmentaryzacją elementów kolekcji (metadane), która zapewni określone możliwości wyszukiwawcze systemu. W tym celu korzystamy z określonych struktur pojęciowych (schematy metadanych, struktury organizacyjne) i terminologii, które zapewnią nam zobiektywizowane i zamknięte przed-rozumienie. Owe struktury pojęciowe są zdeterminowane historycznie, kulturowo i językowo.

(2) Użytkownicy to nie odizolowane umysły posługujące się określonymi strukturami poznawczymi, lecz istoty ludzkie, które współdzielą teoretyczne i praktyczne przed-rozumienie, np. w ramach społeczności zawodowych.

(3) Pojęcie relewancji odnosi się do różnych horyzontów przed-rozumienia. Paradygmat hermeneutyczny zapewnia ramy teoretyczne dla funkcjonowania odmiennych kryteriów relewancji, np. relewancja systemowa, indywidualna czy pertynencja i zakłada konieczność uwzględnienia hermeneutyki użytkowników, zbioru informacji oraz mediacji za pośrednictwem systemu.

Z powyższych rozważań wyłania się obraz określonej postawy poznawczej, która może stanowić podstawy do teoretycznej refleksji nad architekturą informacji zarówno na płaszczyźnie metodologicznej, jak i epistemologicznej. Odkładając na bok rozważania na temat tożsamości AI oraz jej inter- czy też transdyscplinarnego charakteru, wydaje się, że ujęcie hermeneutyczne może wnieść nowe spojrzenie na AI lub uporządkować i ujawnić istniejące podejścia badawcze funkcjonujące w jej ramach.

\footnotetext{
${ }^{5}$ Kwestia całkowitej zamkniętości systemowego horyzontu rozumienia staję się dyskusyjna jeśli uwzględnimy nowe kierunki w projektowaniu systemów informacyjnych oparte na sztucznej inteligencji i uczeniu maszynowym.
} 


\section{Architektura informacji w ujęciu hermeneutycznym}

Na potrzeby dalszych rozważań nad możliwością uwzględnienia perspektywy hermeneutycznej w architekturze informacji zostaną przyjęte pewne założenia, które wyznaczą ramy interpretacji tej koncepcji:

(1) Architektura informacji rozumiana jest tutaj w wąskim ujęciu, które według koncepcji Rosenfelda, Morville i Arrango definiowane jest jako strukturalne projektowanie współdzielonych środowisk informacyjnych.

(2) Przedmiotem AI w wąskim ujęciu są usługi informacyjne (serwisy, systemy, aplikacje), funkcjonujące w środowisku World Wide Web.

(3) Projektowanie strukturalne odnosi się również do projektowania organizacji informacji (w tym systemów organizacji wiedzy).

(4) Model AI uwzględnia trzy kluczowe elementy: kolekcję, która podlega organizacji, użytkowników, ich potrzeby i zachowania informacyjne oraz kontekst determinujący cele i strategię samej usługi informacyjnej.

(5) Metodyka AI zakłada realizację procesu projektowania z wykorzystaniem systemów organizacyjnych, etykietowania, nawigacyjnych i wyszukiwawczych.

(6) Chociaż AI operuje w środowisku multimedialnym, to dużą rolę w projektowaniu i organizowaniu kolekcji pełni język naturalny jako środek ekspresji znaczenia. Dotyczy to zarówno strukturyzacji treści jak i narzędzi dostępu.

W dalszej części artykułu rozważania na temat hermeneutycznej koncepcji architektury informacji są zorganizowane w postaci obszarów problemowych AI, które wpisują się w ujęcie hermeneutyczne.

\subsection{Odrzucenie postulatu o neutralności reprezentacji}

Teza, że każda reprezentacja jest interpretacją pochodzi z książki Terry’ego Winograda i Fernando Floresa Understanding Computers and Cognition (1987), będącej jedną z najważniejszych pozycji na temat roli poznania, języka i interakcji w projektowaniu systemów informacyjnych. Koncepcja Winograda i Floresa jest zanurzona w filozofii hermeneutycznej zarówno w ujęciu metodologicznym, jak i epistemologicznym. Autorzy, nawiązując do hermeneutyki H-G. Gadamera oraz fenomenologii hermeneutycznej M. Heideggera, oferują hermeneutyczną refleksję nad teorią reprezentacji informacji i interakcji człowiek-komputer w odniesieniu do systemów informacyjnych.

W przypadku architektury informacji chodzi o odrzucenie założenia, że celem i naczelną zasadą organizacji informacji w danej kolekcji jest obiektywne i neutralne odwzorowanie pewnej domeny. Założenia dotyczące reprezentacji informacji są uwarunkowane czynnikami kontekstowymi w rozumieniu celów i strategii usługi informacyjnej, ale również horyzontu rozumienia jej użytkowników. Zasadniczym celem użytkownika systemu informacyjnego jest rozwiązanie określonego problemu informacyjnego za pomocą środków i narzędzi, które system ten oferuje. W systemach wyszukiwania informacji strukturyzacja informacji na etapie opisu zasobów informacji warunkuje możliwości jej wyszukania i wykorzystania. Capurro (2000) twierdzi, że otwiera ona możliwości różnych perspektyw interpretacyjnych i nawiązuje do analizy struktury rozumienia M. Heideggera, w której mamy do czynienia z ogólnym tłem pojęciowym, przyjętym konkretnym punktem widzenia oraz właściwą 
terminologią. W przypadku AI oznacza to, że projektant musi zdefiniować pewien obszar wiedzy, korzystając z systemów organizacji wiedzy (np. list..., taksonomii, tezaurusów) przyjmując jednocześnie obecny w nich punkt widzenia. Zastosowane narzędzia (schematy metadanych, systemy organizacji wiedzy) zapewniają możliwość odwzorowania cech elementów organizowanej kolekcji, uznanych za istotne zarówno dla realizacji funkcji informacyjnej, jak i wyszukiwawczej. Mamy więc po jednej stronie zdeterminowane przez projektanta (i zwykle postrzegane przez niego jako zobiektywizowane) przed-zrozumienie, a z drugiej użytkownika z jego horyzontem rozumienia.

To podejście wiąże się również z pojęciem błędu projektanta (ang. designer fallacy), które scharakteryzował Don Ihde w swojej koncepcji filozofii technologii (Ihde, 2006). Tym mianem określa się stanowisko projektanta, w którym zakłada on pełną kontrolę nad znaczeniem obiektów, które tworzy i nie bierze pod uwagę sieci relacji z innymi obiektami, w których te obiekty będą funkcjonowały, użytkowników i sposobów użycia danego obiektu oraz złożonych i wielopłaszczyznowych kontekstów kulturowych (Capurro, 2010, 37). Mamy więc do czynienia z zastosowaniem podejścia hermeneutycznego zarówno na etapie identyfikacji cech elementów kolekcji (schematy organizacyjne), jak również sposobu ich odwzorowania (etykietowanie) oraz włączenia w mechanizmy dostępu (wyszukiwanie i nawigacja).

W tym obszarze podejście hermeneutyczne do AI może oznaczać czerpanie z dorobku teoretycznego organizacji wiedzy, która daje teoretyczną refleksję na temat epistemologii i metodyki projektowania systemów organizacji wiedzy. Hermeneutyczna perspektywa oznacza tutaj tezę, że każdy dokument jest napisany i zinterpretowany z zastosowaniem określonego horyzontu rozumienia. Taka sama sytuacja dotyczy systemów organizacji wiedzy i użytkowników korzystających z nich w procesie wyszukiwania informacji. Każde zapytanie użytkownika do systemu jest skierowane z określonego horyzontu rozumienia. Horyzonty mogą być spójne lub pozostawać w konflikcie. Indeksowanie dokumentu jest próbą umożliwienia użytkownikowi wyszukania relewantnych dokumentów poprzez poznanie tych różnych horyzontów (Hjørland, 2011b, 74).

\subsection{Przed-sady}

W hermeneutycznej koncepcji architektury informacji duże znaczenie ma rola kontekstu w rozumieniu Morville’a i Rosenfelda, ale również pojmowanego za Hintonem jako sposób, w jaki dana osoba postrzega relacje między elementami tworzącymi środowisko jej funkcjonowania. Mając na uwadze fakt, że użytkownicy konstruują swoje przed-sądy na podstawie przeszłych doświadczeń w interakcji z sieciowymi usługami informacyjnymi, projektowanie zarówno interfejsów graficznych, jak i procesów interakcji i w końcu organizacji informacji powinno być oparte na wiedzy o nich. Hermeneutyka bada sposób, w jaki doświadczamy współdzieloną rzeczywistość, nie zajmuje się relatywizmem i mentalizmem. Jest oparta na codziennych doświadczeniach, tym co ludzie robią i co mówią. W przypadku AI stosuje się metodologię badań potrzeb i zachowań użytkowników informacji oraz modelowania grup użytkowników docelowych (np. persony). Hermeneutyczne podejście wymaga jednak spójnej refleksji metodologicznej, która dałaby narzędzia badawcze do identyfikacji przed-sądów użytkowników.

Jednym z rozwiązań może być przeniesienie koncepcji modeli mentalnych na grunt badań w obszarze AI. Przez modele mentalne rozumie się tutaj pewne struktury pojęciowe, 
którymi operują ludzie na temat ich samych, otoczenia w którym funkcjonują, rzeczy z którymi wchodzą w interakcję. Ludzie tworzą modele mentalne poprzez zdobywanie doświadczeń i edukację (Norman, 1988). W odniesieniu do przestrzeni informacyjnych są to kognitywne reprezentacje, które ułatwiają użytkownikowi reprezentację treści informacji i relacji, w jakie w wchodzi w danej przestrzeni. To z kolei pomaga mu w zrozumieniu organizacji tej przestrzeni i poruszaniu się w niej i reagowaniu na sytuacje, które zachodzą podczas tej nawigacji (Chen et al., 1998, 583).

Chociaż każdy model mentalny, którym dysponujemy, jest indywidualny i unikalny, to nie jest on w całości idiosynkratyczny. Tworzymy je nie tylko na podstawie naszych doświadczeń, ale również na podstawie ogólnej wiedzy o świecie i zachowań językowych, które współdzielimy ze społecznościami, których jesteśmy członkami (van Dijk, 2011, 5). Donald Norman (1988) twierdzi, że użytkownicy technologii próbują uzyskać kontrolę nad nimi, tworząc wewnętrzne modele mentalne rzeczy, z którymi wchodzą w interakcję. Pozwalają one konstruować ich własną koncepcję rozumienia, opartą na przewidywaniu i wyjaśnianiu.

Z punktu widzenia użytkownika, emanacją architektury informacji danego systemu informacyjnego są mechanizmy dostępu do informacji, które funkcjonują w jego interfejsie graficznym i sposoby strukturyzacji treści tworzących bazę informacyjną systemu. Mamy więc do czynienia z mechanizmami przeglądania (ang. browsing) i wyszukiwania (ang. searching), które determinują sposób poruszania się użytkownika w tej przestrzeni informacyjnej. Z jednej strony, mamy strukturyzację informacji na etapie projektowania, z drugiej - jej wdrożenie w postaci narzędzi dostępu. Dotyczy to również projektowania hipertekstowej organizacji informacji dla treści udostępnianych w systemie. Istotne jest więc ustalenie, w jaki sposób użytkownik rozumie i interpretuje strukturę tych narzędzi oraz wykładników językowych zastosowanych w ich konstrukcji, a także - czy badania nad modelami mentalnymi tych procesów są w stanie dać nam podstawy do analizy przed-sądów użytkowników? W dyskursie naukowym w informatologii obecne są próby rekonstrukcji modeli mentalnych opisujących proces eksploracji struktur hipertekstowych (np. Chen et al., 1998; Holman, 2011; Schreder et al., 2016; Zhang, 2010). Birger Hjørland proponuje, aby w tego typu badaniach uwzględnić perspektywę metateoretyczną i skłania się w stronę hermeneutyki (Hjørland, 2011a). Twierdzi, że projektowanie lub sterowanie procesem przeglądania powinno uwzględniać nie tylko psychologiczne preferencje użytkownika, ale również pewną perspektywę teoretyczną, którą przyjęli projektanci systemu i która wyznacza sposób organizacji informacji. Chodzi tu więc o systemowy horyzont rozumienia, którego emanacją są m.in. narzędzia dostępu, np. w postaci nawigacji.

W przypadku architektury informacji sieciowych usług informacyjnych koncepcja przed-sądów może być rozumiana zarówno w odniesieniu do wstępnych założeń użytkowników co do typu serwisu internetowego lub aplikacji (np. sklep internetowy, blog, portal informacyjny), jak również do ich elementów strukturalnych i funkcjonalnych. Chodzi więc o świadomość wstępnego rozumienia, jakim posługują się użytkownicy, do których kierowana jest dana usługa lub aplikacja. W przypadku badań nad przed-sądami użytkowników w kontekście AI należy również dokonać rozróżnienia na płaszczyznę organizacji i płaszczyznę prezentacji informacji.

W pierwszym przypadku mówimy o projektowaniu pewnej oferty znaczeniowej (ang. meaning offer), która będzie wyznaczać horyzont rozumienia systemu i bez której ujawnienia nie zachodzi proces interpretacji. Capurro dobitnie stwierdza, że bez oferty znaczeniowej 
nie ma mowy o interpretacji (Capurro, 2010, 39). Właściwe zaprojektowanie oferty znaczeniowej wydaje się więc zasadniczym celem architektury informacji. Środkiem ekspresji owej oferty znaczeniowej są według koncepcji Rosenfelda i Morville’a systemy organizacyjne, etykietowania, nawigacji i wyszukiwania. Hinton $(2014,352)$ proponuje inną nomenklaturę: etykiety (ang. labels), relacje (ang. relationships) i zasady (ang. rules). Przez „etykiety” rozumie on nazwy nadawane zarówno elementom kolekcji i ich cechom, jak i kategoriom tematycznym wykorzystywanym do eksploracji kolekcji. „Relacje” według Hintona powinny mieć charakter sytuacyjny, tzn. łączyć elementy kolekcji zależnie od przyjętego w danym systemie rozumienia pojęcia kontekstu. Twierdzi on, że podejście fasetowe zapewnia nielinearne sposoby doświadczania przez użytkowników kontekstu i daje szanse na współistnienie wielu perspektyw interpretacji i tym samym wielu możliwych sposobów dotarcia do informacji (Hinton, 2014, 363). W końcu „zasady” to zbiór ograniczeń nakładanych na serwis w procesie jego projektowania, które określają zakres możliwych czynności i akcji, jakie może podejmować wobec niego użytkownik. Chodzi tu nie tyle o sterowanie interakcją, co dostosowywanie się do zachowań użytkownika i asystowanie w procesach, które on podejmuje podczas interakcji.

Zarówno w ujęciu Hintona jak i Rosenfelda i Morville’a są to narzędzia wspomnianej wcześniej strukturyzacji i reprezentacji informacji, dla których hermeneutyczną perspektywę proponuje Capurro. Warto podkreślić fakt, że to językowe środki ekspresji znaczenia odgrywają tutaj kluczową rolę. Hermeneutyka zakłada, że przed-sądy, które wpływają na sposób naszej interpretacji, są obecne w języku, którym się posługujemy. I chociaż mają one charakter indywidualny, to są zdeterminowane kontekstem społecznym i kulturowym, w którym funkcjonujemy. Ciekawą i wartą rozważenia propozycją byłaby konfrontacja założeń teoretycznych AI z koncepcją etnosemantyki oraz elementami filozofii języka Ludwiga Wittgensteina. Te dwa podejścia widoczne są w badaniach nad projektowaniem systemów organizacji wiedzy (np. Beghtol, 1986; Mai, 1998), z których czerpie AI.

Jednym z założeń etnosemantyki jest teza, że członkowie danej społeczności (lub w szerszym ujęciu - kultury) współdzielą struktury pojęciowe (klasyfikacje) reprezentujące świat, który ich otacza. To z kolei jest podstawą dla komunikacji, sensownych zachowań oraz właściwych osądów. Wspomniane struktury pojęciowe są zakodowane w systemie znaczeniowym języka. Poprzez badanie semantyki języka jesteśmy w stanie poznać kulturowe kategorie poznawcze, które w nim funkcjonują i które pełnią funkcje kodu kulturowego danej społeczności. Każdy kompetentny członek danej społeczności zna zasady tego kodu, co pozwala mu na właściwą interpretację zjawisk zachodzących wewnątrz społeczności. W związku z tym, interpretacja jest podstawą wszelkich akcji i interakcji (Eglin, 1980, 28-29). AI w wąskim ujęciu nie operuje co prawda na poziomie kultury, ale konfrontując to stanowisko z rolą kontekstu (m.in. kultura organizacyjna) wydaje się, że taka perspektywa poznawcza może znaleźć swoje uzasadnienie w projektowaniu przestrzeni informacyjnych.

Drugim podejściem, które wpisuje się w hermeneutyczną koncepcję AI, jest zastosowanie koncepcji znaczenia jako użycia oraz gry językowej według filozofii Ludwiga Wittgensteina. Twierdził on, że aby zrozumieć znaczenie jakiegoś wyrażenia, należy być częścią praktyki językowej, w której ono funkcjonuje. Wittgenstein traktował język instrumentalnie, słowa miały pełnić funkcję narzędzi. Ich znaczenie konstytuuje się w grach językowych - użyciu języka w określonych kontekstach, czyli całości złożonej z języka i czynności, w które jest on wpleciony (Wittgenstein, 2000, $\$ 7$ ). Słowa nie są definiowane poprzez przedmiot ich 
odniesienia, lecz cel i funkcję ich użycia w danym kontekście (Mai, 1998, 238). Wittgenstein pisze, że „wyobrazić sobie język to wyobrazić sobie pewną formę życia” (Wittgenstein, 2000, $\$ 12$ ). Forma życia jest ogółem zachowań regularnych charakterystycznych dla społeczności jako całości, a nie dla poszczególnych jej członków. Jest przestrzenią podstawowej zgodności w języku, która jest między innymi zgodnością pewnego fundamentalnego obrazu świata (Gomulka \& Szafrański, 2009, 59). Wittgenstein twierdził, że wyrażenie rozumieć coś nabiera sensu tylko w odniesieniu do określonego kontekstu, który nazywał obrazem świata. Jest to system jawnych i ukrytych założeń na temat świata, w którym żyjemy. AI operuje językiem jako środkiem ekspresji oferty znaczeniowej. Użytkownicy usług informacyjnych operują językiem podczas ekspresji ich potrzeb informacyjnych i eksploracji przestrzeni informacyjnej. W związku z tym, zasadne jest postawienie pytania, czy użycie języka zarówno w projektowaniu jak i poruszaniu się w przestrzeni informacyjnej może być interpretowane w kontekście gier językowych, a jeśli tak to czy możemy mówić o celach i regułach tych gier.

Gdy spojrzymy na architekturę informacji z punktu widzenia doświadczeń użytkownika (ang. user experience), koncepcja przyjazności użytkownikowi nabiera nowego znaczenia. J. E. Mai $(1998,240)$ twierdzi, że być zorientowanym na użytkownika oznacza tutaj organizację i reprezentację wiedzy w sposób najbardziej zbliżony do sposobu myślenia użytkowników, czyli ich obrazów świata. To jednak wydaje się być niemożliwe, dlatego też zdaniem Maia to użytkownicy powinni mieć możliwość zrozumienia form życia oraz obrazu świata, który ukształtował daną usługę informacyjną. Odpowiedzialność za efektywność wyszukiwania jest po stronie użytkownika, zaś za właściwą organizację i reprezentację wiedzy po stronie usługi informacyjnej.

W odniesieniu do przed-sądów na płaszczyźnie prezentacji informacji mówimy o architekturze interfejsu graficznego oraz sposobie funkcjonowania jego elementów strukturalnych. W tym obszarze z pomocą mogą przyjść badania nad użytecznością prowadzone na określonych i spójnych grupach respondentów lub w odniesieniu do konkretnego typu serwisów internetowych. W tym nurcie mieszą się np. badania na temat oczekiwanego przez użytkownika rozmieszczenia elementów funkcjonalnych w interfejsie graficznym serwisu internetowego (np. Lynch \& Horton, 2009), sposobem porządkowania kategorii tematycznych w schematach nawigacyjnych, kryteriami relewancji i sortowania rezultatów wyszukiwania. Hinton $(2014,389)$ proponuje również zastosowanie metodologii projektowania kontekstowego (ang. contextual design) szczególnie w wydaniu Beyer \& Holtzblatt (1998), która bazuje na założeniach interakcji człowiek-komputer, ale uwzględnia zastosowanie metod badań etnograficznych. Co prawda metodologia ta nie eksponuje tak silnie koncepcji znaczenia jak etnosemantyka, ale przyjmuje istotną rolę języka w procesie interakcji.

\subsection{Interakcja jako konwersacja}

Według filozofii hermeneutycznej Gadamera proces rozumienia zachodzi w trakcie konwersacji, w której to następuje wymiana informacji pomiędzy partnerami rozmowy, którzy poszukują porozumienia w określonej sprawie. Tym samym rozumienie jako fuzja horyzontów zachodzi w procesie konwersacji, która jest zdeterminowana językowo. Gadamer twierdził, że proces rozumienia wymaga „wspólnego języka”, chociaż ten i tak formułuje się w jakimś stopniu w procesie rozumienia. Tym samym każde rozumienie ma charakter 
interpretatywny i polega na wymianie z tym, który jest obcy, ma więc również charakter translatoryczny (Malpas, 2016). W związku z tym, że w przypadku architektury informacji w serwisach informacyjnych wzajemne oddziaływanie na siebie użytkownika i systemu może być rozpatrywane przede wszystkim w kontekście interakcji, należy postawić pytanie, czy interakcja może być traktowana tutaj jako hermeneutyczny proces fuzji horyzontów (użytkownika i systemu), a jeśli tak, to jaka jest rola organizacji przestrzeni informacyjnej w procesie interpretacji i rozumienia jej elementów przez użytkownika. W tym miejscu wkraczamy na pole badawcze interakcji człowiek-komputer, jednak ten obszar wydaje się mieć duży wpływ zarówno na architekturę informacji, jak i projektowanie doświadczeń użytkownika.

Proces interakcji użytkownika z systemem w ujęciu hermeneutycznym można przeanalizować, odwołując się do teorii inżynierii semiotycznej (ang. semiotic engineering), w której przyjmuje się, że systemy interaktywne są zbudowane z komunikatów wysokiego poziomu (ang. high-level messages), nadanych przez projektanta do użytkowników, na temat tego w jaki sposób komunikować się z systemem w procesie osiągania określonego rodzaju celów. Wiadomości od projektanta do użytkownika mają postać metakomunikacyjnych artefaktów, aktów performatywnych realizujących wymianę komunikatów między użytkownikiem i projektantem (De Souza et al. 2001, 479). W ramach tej teorii projektowanie interakcji traktuje się jako projektowanie konwersacji, przy czym rozmowa ta ma wyjątkowy charakter ponieważ projektant nie jest obecny w trakcie jej trwania (Barbosa \& De Paula, 2003, 18). Zamiast projektanta w interfejsie graficznym obecne są elementy funkcjonalne, które pełnią rolę jego rzecznika (ang. designer's spokesman). Projektant jest odpowiedzialny za skonstruowanie swojego rzecznika w postaci odpowiedniego repertuaru „tematów” rozmów, które mogą mieć miejsce podczas konwersacji z użytkownikiem (Bueno \& Barbosa, 2007, 12). Model ten zakłada postrzeganie konwersacji jako interakcji w kontekście intencji użytkowników oraz zakresu obowiązków systemu.

Model interakcji jako konwersacji uzasadnia postrzeganie AI również w kontekście dynamicznej fuzji horyzontów. Dynamika tego procesu jest przede wszystkim po stronie użytkownika i zmian w jego horyzoncie rozumienia. Horyzont systemu, co już wskazano wcześniej, jest zamknięty i zobiektywizowany za pośrednictwem języka, który został użyty do jego konstrukcji. Jest biernym uczestnikiem procesu interakcji w rozumieniu możliwości jego zmian. O ile zatem architektura informacji danego systemu w rozumieniu oferty znaczeniowej ma charakter statyczny, tzn. opiera się na przyjętym sposobie strukturyzacji treści, o tyle jej aktywizacja za pośrednictwem narzędzi dostępu jest realizowana poprzez interakcję użytkownika z systemem. Tym razem wkraczamy na pole projektowania interakcji (ang. interaction design), ale to właśnie modelowanie interakcji wydaje się być dopełnieniem obrazu organizacji informacji w danej kolekcji. Chodzi bowiem o projektowanie i przewidywanie sposobów eksploracji przestrzeni informacyjnych przez użytkownika w ramach ich architektury informacji. Dotyczy to w dużej mierze projektowania interakcji zdeterminowanego przez przyjęte wymogi funkcjonalne systemu, ale te mogą być przecież realizowane przez użytkownika na różne sposoby. Tutaj również z pomocą może przyjść koncepcja modeli mentalnych. W przypadku interakcji z technologią informacyjną możemy wyróżnić dwa podstawowe rodzaje modeli mentalnych - strukturalne i funkcjonalne. Modele strukturalne opierają się na zinternalizowanej wiedzy na temat tego jak działa dany system lub urządzenie. Modele funkcjonalne operują zinternalizowaną 
wiedzą proceduralną jak korzystać z danego systemu lub urządzenia (Kurtz, 2003). Modele funkcjonalne w przeciwieństwie do strukturalnych są zależne od kontekstu i są tworzone na podstawie przeszłych i podobnych doświadczeń. Modele strukturalne zaś ułatwiają zrozumienie nieoczekiwanych zdarzeń podczas interakcji z systemem lub urządzeniem. W takiej perspektywie proces rozumienia, czyli fuzja horyzontów zachodzi dzięki zaistnieniu „wspólnego języka” użytkownika i systemu oraz konwersacji, która ma miejsce w ramach przyjętego zakresu funkcjonalności systemu i środków ich realizacji.

\section{Podsumowanie}

Przedstawione rozważania na temat postrzegania architektury informacji w ujęciu hermeneutycznym jedynie dotykają tej problematyki. Celem artykułu było zainicjowanie dyskusji na temat teoretycznych i epistemologicznych założeń architektury informacji, proponując jednocześnie ujęcie hermeneutyczne. Chociaż postawy poznawcze charakterystyczne dla hermeneutyki i fenomenologii hermeneutycznej widoczne są w dyskursie w ramach architektury informacji, to mają one charakter raczej heurystyk, nie zaś spójnej refleksji metodologicznej. Hermeneutyczna interpretacja architektury informacji wymaga więc pogłębionych analiz na temat roli rozumienia i interpretacji w projektowaniu informacji (ang. information design), organizacji informacji oraz modelowaniu interakcji. W tych obszarach widoczne są próby zastosowania filozofii hermeneutycznej lub jej elementów, ale nie odbywa się to pod szyldem architektury informacji.

\section{Bibliografia}

Akker, C. van den, Oomen, J., Jacobs, G., Legêne, S., van Erp, M., Aroyo, L., Wielinga, B. (2011). Digital Hermeneutics: Agora and the Online Understanding of Cultural Heritage [online]. Proceedings of the 3rd International Web Science Conference on - WebSci '11, 1-7. New York: ACM. https:// doi.org/10.1145/2527031.2527039

Arango, J. (2018). Living in Information: Responsible Design for Digital Places. New York: Two Waves Books.

Barbosa, S. D. J., De Paula, M. G. (2003). Designing and Evaluating Interaction as Conversation: A Modeling Language Based on Semiotic Engineering. In: J. A. Jorge, J. N. Nuno, F. e C. João (Eds.), Interactive Systems. Design, Specification, and Verification [online], vol. 2844, 16-33. Berlin: Springer. https://doi.org/10.1007/978-3-540-39929-2_2

Beghtol, C. (1986). Semantic Validity: Concepts of Warrant in Bibliographic Classification Systems. Library Resources \& Technical Services, April/June, 109-125.

Beyer, H., Holtzblatt, K. (1998). Contextual Design : Defining Customer-Centered Systems. Burlington, MA: Morgan Kaufmann.

Brown, D. (2010). Eight Principles of Information Architecture [online]. Bulletin of the American Society for Information Science and Technology, 36(6), 30-34. https://doi.org/10.1002/ bult.2010.1720360609

Bueno, A. M., Barbosa, S. D. J. (2007). Using an Interaction-as-Conversation Diagram as a Glue Language for HCI Design Patterns on the Web. Lecture Notes in Computer Science (Including Subseries Lecture Notes in Artificial Intelligence and Lecture Notes in Bioinformatics) [online], 4385 LNCS, 122-136. https://doi.org/10.1007/978-3-540-70816-2_10 
Capurro, R. (2000). Hermeneutics and the Phenomenon of Information. In: C. Mitcham (Ed.), Metaphysics, Epistemology, and Technology. Research in Philosophy and Technology, Vol. 19, (79-85). Amsterdam: Elsevier.

Capurro, R. (2010). Digital Hermeneutics: An Outline [online]. AI and Society, 25(1), 35-42. https:// doi.org/10.1007/s00146-009-0255-9

Chalmers, M. (2004). Hermeneutics, Information and Representation [online]. European Journal of Information Systems, 13(3), 210-220. https://doi.org/10.1057/palgrave.ejis.3000504

Chen, H., Houston, A. L., Sewell, R. R., Schatz, B. R. (1998). Internet Browsing and Searching: User Evaluations of Category Map and Concept Space Techniques [online]. Journal of the American Society for Information Science, 49(7), 582-603. https://doi.org/10.1002/(SICI)1097-4571(19980515)49:7<582::AID-ASI2>3.0.CO;2-X

Cole, M., Avison, D. (2007). The Potential of Hermeneutics in Information Systems Research [online]. European Journal of Information Systems, 16(6), 820-833. https://doi.org/10.1057/palgrave. ejis. 3000725

De Souza, C. S., Barbosa, S. D. J., Da Silva, S. R. P. (2001). Semiotic Engineering Principles for Evaluating End-user Programming Environments [online]. Interacting with Computers, 13(4), 467-495. https://doi.org/10.1016/S0953-5438(00)00051-5

Dijk, T. A. van (2011). Discourse Studies and Hermeneutics [online]. Discourse Studies, 13(5), 609-621. https://doi.org/10.1177/1461445611412762

Dillon, A. (2002). Information Architecture in JASIST: Just Where Did We Come From? [online]. Journal of the American Society for Information Science and Technology, 53(10), 821-823. https:// doi.org/10.1002/asi.10090

Eglin, P. (1980). Talk and Taxonomy: A Methodological Comparison of Ethnosemantics and Ethnomethodology with Reference to Terms for Canadian Doctors. Amsterdam: John Benjamins Publishing Company.

Gadamer, H-G. (2013). Prawda i metoda : zarys hermeneutyki filozoficznej. Warszawa: Wydaw. Naukowe PWN.

Gomulka, J., Szafrański, M. (2009). Wittgensteinowska „forma życia” i biologiczne podstawy gramatyki. Semina Scientiarum, 8, 56-78.

Hagedorn, K. (2000). Information Architecture Glossary [online]. Argus Associates [20.10.2019], http://argus-acia.com/white_papers/ia_glossary.pdf

Haverty, M. (2002). Information Architecture without Internal Theory: An Inductive Design Process [online]. Journal of the American Society for Information Science and Technology, 53(10), 839-845. https://doi.org/10.1002/asi.10096

Heidegger, M. (2008). Bycie i czas. Warszawa: Wydawnictwo Naukowe PWN.

Hinton, A. (2014). Understanding Context: Environment, Language, and Information Architecture. Sebastopol: O’Reilly Media.

Hjørland, B. (2011). The Importance of Theories of Knowledge: Browsing as an Example [online]. Journal of the American Society for Information Science, 62(3), 594-603. https://doi.org/10.1002/asi

Hjørland, B. (2011). The Importance of Theories of Knowledge: Indexing and Information Retrieval as an Example [online]. Journal of the American Society for Information Science and Technology, 62(1), 72-77. https://doi.org/10.1002/asi.21451

Holman, L. (2011). Millennial Students' Mental Models of Search: Implications for Academic Librarians and Database Developers [online]. The Journal of Academic Librarianship, 37(1), 19-27. https://doi.org/10.1016/j.acalib.2010.10.003

Ihde, D. (2006). The Designer Fallacy and Technological Imagination. In: J. R. Dakers (Ed.) Defining Technological Literacy Towards an Epistemological Framework [online]. London: Palgrave Macmillan, 121-131. https://doi.org/10.1057/9781403983053

Ilnicki, R. (2012). Fenomenologia i hermeneutyka kodu. Homo Communicativus, 1(7), 47-54. 
Jahnke, M. (2011). Towards a Hermeneutic Perspective on Design Practice [online]. KTH. Designfakulteten [20.10.2019], http://www.designfakulteten.kth.se/sites/default/files/towardsahermeneuticperspectiveondesignpractice_finalversion_jahnke.pdf

Kurtz, A. (2003). Mental Models - A Theory Critique [online]. Wev Archive [20.10.2019], https:// web.archive.org/web/20180217164118/mcs.open.ac.uk/yr258/ment_mod

Lacerda, F., Lima-Marques, M. (2014). Information Architecture as a Discipline - A Methodological Approach. In: A. Resmini (ed.), Reframing Information Architecture [online] (1-10). Cham: Springer. https://doi.org/10.1007/978-3-319-06492-5_1

Lynch, P., Horton, S. (2009). Presenting Information Architecture [online]. Web Style Guide [20.10.2019], https://webstyleguide.com/wsg3/3-information-architecture/4-presenting-information.html

Mai, J. (1998). Organization of Knowledge: An Interpretive Approach. Proceedings of the Annual Conference of CAIS/Actes Du Congrès Annuel de l'ACSI [online], 1998, https://doi.org/10.29173/ cais434

Malpas, J. (2016). Hans-Georg Gadamer. In: Stanford Encyclopedia of Philosophy [online]. Stanford University [20.10.2019], https://plato.stanford.edu/entries/gadamer/

Mantzavinos, C. (2016). Hermeneutics. In: Stanford Encyclopedia of Philosophy [online]. Stanford University [20.10.2019] https://plato.stanford.edu/entries/hermeneutics/

Maszkiewicz, M. (2015). Hermeneutyka i teoria intertekstualności jako metodologia badań modernizmu w poezji serbskiej drugiej połowy XX w. na przykładzie cyklu „Deset soneta nerođenoj kćeri” Ivana V. Lalicia [online]. Adeptus, (6), 1-10. https://doi.org/10.11649/a.2015.009

Materska, K. (2017). Ekologia informacji. In: A. Żbikowska-Migoń, M. Skalska-Zlat (Eds.) Encyklopedia Ksiażki (611). Wrocław: Wydaw. Uniwersytetu Wrocławskiego.

Mazzocchi, F., Bosch, M. (2008). Hermeneutic Approaches in KO: An Analysis of Their Possible Value. Advances in Knowledge Organization, 11, 29-35.

Morville, P. (2005). Ambient Findability: What We Find Changes Who We Become. Sebastopol: O'Reilly Media.

Morville, P. (2014). Intertwingled: Information Changes Everything. Ann Arbor, Michigan: Semantic Studios.

Morville, P., Rosenfeld, L. (1998). Information Architecture for the World Wide Web. Designing Large-Scale Web Sites. Sebastopol: O’Reilly Media.

Morville, P., Rosenfeld, L. (2002). Information Architecture for the World Wide Web. Designing Large-Scale Web Sites (2nd Edition). Sebastopol: O’Reilly Media.

Morville, P., Rosenfeld, L. (2008). Information Architecture for the World Wide Web. Designing Large-Scale Web Sites (3rd Edition). Sebastopol: O’Reilly Media.

Morville, P., Rosenfeld, L., Arango, J. (2015). Information Architecture. For the Web and Beyond. Sebastopol: O'Reilly Media.

Myers, M. D. (1994). Dialectical Hermeneutics: A Theoretical Framework for the Implementation of Information Systems [online]. Information Systems Journal, 5(1), 51-70. https://doi.org/10.1111/j.1365-2575.1995.tb00089.x

Norman, D. (1988). The Psychology of Everyday Things. New York: Basic Books Inc.

Oziębłowski, M. (2006). Granica czy most? O funkcjach rozumienia w hermeneutyce H.-G. Gadamera. Diametros, 10, 65-77.

Przyłębski, A. (2006). Gadamer. Wiedza Powszechna.

Resmini, A, Rosati, L. (2011). A Brief History of Information Architecture [online]. Journal of Information Architecture, 3(2) [20.10.2019], http://journalofia.org/volume3/issue2/03-resmini/

Resmini, A. (2013). Architectures of Information [online]. Études De Communication, (41), 31-56. https://doi.org/10.4000/edc.5630

Resmini, A. (Ed.). (2014). Reframing Information Architecture [online]. Springer International Publishing. https://doi.org/10.1007/978-3-319-06492-5 
Resmini, A., Rosati, L. (2011). Pervasive Information Architecture. Pervasive Information Architecture [online]. Burlington, MA: Morgan Kaufmann. https://doi.org/10.1016/C2009-0-63576-5

Schreder, G., Windhager, F., Smuc, M., Mayr, E. (2016). A Mental Models Perspective on Designing Information Visualizations for Political Communication [online]. JeDEM - EJournal of EDemocracy and Open Government, 8(3), 80-99. https://doi.org/10.29379/jedem.v8i3.443

Skórka, S. (2002). Architektura informacji. Nowy kierunek rozwoju informacji naukowej [online]. EBIB, (11). (20.10.2019), http://www.ebib.pl/2002/40/skorka.php

Skórka, S. (2016a). Architektura informacji. W: W. Babik (red.), Nauka o informacji (555-576). Warszawa: Stowarzyszenie Bibliotekarzy Polskich.

Skórka, S. (2016b). Nowe wyzwania architektury informacji. Bibliotheca Nostra: Biuletyn Informacyjny, (2), 10-22.

Tafiłowski, P. (2016). Architektura informacji jako problem badawczy informatologii. Zagadnienia Informacji Naukowej. Studia Informacyjne, 54(2), 34-47.

Voida, A. (2008). Exploring a Technological Hermeneutic: Understanding the Interpretation of Computer-Mediated Messaging Systems [online]. Georgia Tech Library [20.10.2019], http://hdl.handle. net/1853/24744

Winograd, T., Flores, F. (1987). Understanding Computers and Cognition: A New Foundation for Design. Reading: Addison-Wesley Professional.

Wittgenstein, L. (2000). Dociekania filozoficzne. Warszawa: Wydaw. Naukowe PWN.

Wodtke, C. (2001). Defining the Damn Thing [online]. Eleganthack [20.10.2019], http://eleganthack. com/defining-the-damn-thing/

Zhang, Y. (2010). Dimensions and Elements of People's Mental Models of an Information-rich Web Space [online]. Journal of the American Society for Information Science and Technology, 61(11), 2206-2218. https://doi.org/10.1002/asi.21406

\title{
Every Representation is an Interpretation: A Hermeneutic Approach to Information Architecture
}

\begin{abstract}
Purpose/Thesis: This paper attempts to provide a generalized conceptual framework on information architecture (IA) based on hermeneutics both as a theory and epistemic stance. The starting point for consideration is the acknowledgment of understanding and interpretation as major factors in IA design and research developed by L. Rosenfeld, P. Morville, and J. Arango.

Approach/Methods: This study is based on the interpretative approach to IA model developed by L. Rosenfeld, P. Morville, and J. Arango, taking as a framework foundational concepts of H.G. Gadamer's hermeneutics and R. Capurro's digital hermeneutics.

Results and conclusions: A hermeneutic approach to IA entails a specific epistemic stance, where we acknowledge cultural and contextual implications for knowledge organization, and we are using the concept of pre-judgments which constitute the user's horizon of understanding. For IA it means that we are designing a meaning offer that is represented by organization systems and externalized by navigation, labeling, and search systems. The process of understanding this meaning offer is based on the fusion of horizons - the open and evolving user's horizon of understanding, and closed fixed system's horizon. This process takes place during the specific act of conversation between user and system, which is framed by the model of interaction.

Originality/Value: There are pieces of evidence of epistemic stances of hermeneutics and phenomenological hermeneutics in IA discourse, but they are rather heuristics, not consistent theoretical
\end{abstract}


programs. The proposed outline of the hermeneutic approach to IA may be used as a starting point for further discussion about the theory of IA, especially for seeing IA as an academic discipline.

\section{Keywords}

Digital Hermeneutics. Hermeneutics. Human-Computer Interaction. Information Architecture. Information Organization.

Dr MARCIN ROSZKOWSKI jest adiunktem w Katedrze Informatologii na Wydziale Dziennikarstwa, Informacji i Bibliologii Uniwersytetu Warszawskiego. Jest cztonkiem International Society for Knowledge Organization oraz Komitetu ds. ontologii w projekcie DBpedia. Jego zainteresowania naukowe obejmuja problematykę organizacji wiedzy i reprezentacji informacji w środowisku sieciowym ze szczególnym uwzględnieniem modelowania konceptualnego systemów informacyjnych oraz metadanych i ontologii sieciowych. Najważniejsze publikacje: B. Sosińska-Kalata, M. Roszkowski: Organizacja informacji i wiedzy (Nauka o informacji, Warszawa, 2016); M. Roszkowski, W. Mustafa El Hadi: The Role of Digital Libraries as Virtual Research Environments for the Digital Humanities (Advances in Knowledge Organization, vol. 15, Würzburg, 2016); M. Roszkowski: Kartoteka haset wzorcowych jako ustuga sieciowa - automatyczna identyfikacja nazw osobowych z wykorzystaniem kartoteki VIAF (Bibliografia - teoria, praktyka, dydaktyka, Warszawa, 2016).

Kontakt $z$ autorem:

m.roszkowski@uw.edu.pl

Katedra Informatologii

Wydziat Dziennikarstwa, Informacji i Bibliologii

Uniwersytet Warszawski

Krakowskie Przedmieście 69

00-927 Warszawa 